\title{
Prevalence of and Risk Factors for Diseases in Korean Americans and Native Koreans Undergoing Health Checkup
}

\author{
So Young Jo', Hyojin Park²,*, Byoung Kwon Lee ${ }^{1,2}$, Su Jung Baik', Hyun Ju Lee', Yoo Mi Park' \\ ${ }^{1}$ Health Promotion Center, Institute of Gastroenterology, Gangnam Severance Hospital, Yonsei University College of Medicine, Seoul, Korea \\ ${ }^{2}$ Department of Internal Medicine, Gangnam Severance Hospital, Yonsei University College of Medicine, Seoul, Korea
}

\begin{abstract}
Background: Korean Americans constitute the fifth largest subgroup in the Asian American population. Despite their increasing population, research and guidelines regarding their health status assessment and disease screening are lacking. This study aimed to compare the prevalence of diseases in Korean Americans and native Koreans to determine the risk factors and guidelines for disease screening.

Methods: Patients who visited the Gangnam Severance Hospital from February 2010 to May 2015 for a health checkup were enrolled in this study. Baseline characteristics, laboratory data, and the organs (stomach, colon, thyroid, brain, prostate, lung, liver, kidney, pancreas, adrenal gland, and heart) of patients were examined. Data regarding patients' dietary patterns were also obtained. Overall, 1,514 Korean Americans (group 1) and 1,514 native Koreans (group 2) were enrolled.

Results: The following diseases were more prevalent in group 1 than in group 2: reflux esophagitis (12.9\% vs. $10 \%)$, gastric ulcer (3.0\% vs. $5.5 \%)$, colorectal polyp (37.7\% vs. $28.7 \%$ ), hemorrhoids (32.2\% vs. $29.9 \%$ ), and benign prostatic hyperplasia (30.2\% vs. $14.3 \%$ ). Although not statistically significant, coronary artery disease has a high prevalence rate of $>20 \%$ in both groups. Dietary patterns were not significant between the two groups.

Conclusion: This study showed that the prevalence of several diseases in Korean Americans differed from that observed in native Koreans. Therefore, a foundation for setting up new guidelines for disease screening among Korean Americans is established.
\end{abstract}

Keywords: Korean Americans; Health Status; Disease; Screening

Received: January 25, 2018, Revised: August 10, 2018, Accepted: August 14, 2018

*Corresponding Author: Hyojin Park https://orcid.org/0000-0003-4814-8330

Tel: +82-2-2019-3318, Fax: +82-2-3463-3882, E-mail: HJPARK21@yuhs.ac 


\section{INTRODUCTION}

In Korea, cancer is the leading cause of death among adults aged over 30 years. Therefore, its prevention is extremely important. The implementation of a 10-year plan for national cancer control has contributed to the prolongation of life by reducing cancer incidence and mortality among Koreans. ${ }^{1)}$ Korean guidelines for screening patients with stomach, liver, colorectal, and breast cancer were developed by health professionals from various academic societies. ${ }^{2)}$ With efforts provided by the Korean government, native Koreans can easily avail health screening services for the early detection of cancer or other chronic diseases. The number of immigrants in the United States is continuously increasing, especially from Asia. Korean Americans constitute the fifth largest Asian American subgroup with a population of approximately 18.2 million in 2011. Korean Americans are supplied with insufficient health service, research, and policy. Even though cancer is the leading cause of death among Korean Americans, cancer screening rates among Korean Americans are consistently lower than the goals specified in the Healthy People 2020 program. ${ }^{3,4)}$ Korean Americans are confronted with multiple barriers for accessing cancer screening information and services, including low English-language proficiency levels that can lead to health/medical literacy issues and lack of health insurance. ${ }^{5)}$ Additionally, only a few studies have focused on cancer incidence in Korean Americans. ${ }^{5)}$ These barriers have prompted Korean Americans to visit South Korea to receive effective healthcare services. Despite the rapid influx of Korean Americans coming to Korean to avail healthcare services, whether they have similar disease prevalence with native Koreans and whether the Korean guidelines for screening cancer are applicable remains unclear. Hence, we aimed to compare the prevalence of diseases among Korean Americans and native Koreans to determine the risk factors and guidelines for disease screening.

\section{METHODS}

\section{Study Population and Data Collection}

A cross-sectional study was conducted on patients who presented for a health checkup at Gangnam Severance Hospital, Yonsei University College of Medicine from February 2010 to May 2015. We gathered data of 1,514 Korean Americans who voluntarily visited South Korea for health status assessment through the health checkup program. For patients repeatedly screened every few years, the first screening results were used for this study. Then, we selected 1,514 age-sex-matched native Koreans living in South Korea who underwent the same health assessment at our center during the same period. Written informed consent was obtained from all participants. Patients' baseline characteristics, laboratory data, and organs (stomach, colon, thyroid, brain, prostate, lung, liver, kidney, pancreas, adrenal gland, and heart) were examined. Esophagogastroduodenoscopy and colonoscopy were performed to determine the occurrence of any gastrointestinal disease. Additionally, thyroid ultrasonography, transrectal prostate ultrasonog- raphy, brain computed tomography (CT)/magnetic resonance imaging, abdominal pelvic CT, high-resolution CT of the lung, and coronary CT angiography were performed to identify the occurrence of other diseases. Moreover, data on patients' dietary patterns were obtained using the health checkup medical questionnaire. Dietary patterns were estimated using the 20-item questionnaire, comprising the following items: three meals a day; meals at the appointed time; time for one meal; overeating; eating out; water drinking (6-8 cups of water); interest in nutrition; frequency grain, protein, vegetable, vegetable oil, fruit, milk and dairy product, sugary food, salty food, greasy food, egg yolk, coffee and infusion, and hot and spicy seasoning consumption; and drinking frequency. Data of all participants were assessed, and differences between Korean Americans and native Koreans were compared.

\section{Ethics Statement}

The present study protocol was reviewed and approved by the Institutional Review Board of Gangnam Severance Hospital (approval no., 2018001). Written informed consents were obtained.

\section{Definition and Assessment of Diseases}

Body mass index (BMI) was measured based on patients' height and weight. Patients with BMI of $>25 \mathrm{~kg} / \mathrm{m}^{2}$ were considered obese. Patients were diagnosed with hypertension if their systolic blood pressure was $\geq 140 \mathrm{~mm} \mathrm{Hg}$ and diastolic blood pressure was $\geq 90 \mathrm{~mm} \mathrm{Hg}$. Lipid profiles were classified as follows: high total cholesterol $(\geq 240$ $\mathrm{mg} / \mathrm{dL}$ ), high low-density lipoprotein (LDL) ( $\geq 160 \mathrm{mg} / \mathrm{dL}$ ), low highdensity lipoprotein (HDL) ( $<40 \mathrm{mg} / \mathrm{dL}$ ), and high triglycerides (TG) ( $\geq 200 \mathrm{mg} / \mathrm{dL}$ ). Reflux esophagitis, peptic ulcer, gastric cancer, colorectal polyp, colorectal cancer (CRC), and hemorrhoid were diagnosed through endoscopic or pathological examination. Coronary artery disease (CAD) was diagnosed using coronary CT angiography and was assessed using the Agatston score. Other diseases were also diagnosed using imaging studies.

\section{Statistical Analysis}

A 1:1 propensity score matching between Korean Americans and native Koreans was performed. A propensity score of Korean Americans was estimated using a logistic-regression model fit with age and sex. A propensity-score-matched cohort was created by attempting to match each American Korean with native Korean (a 1:1 match). A nearestneighbor-matching algorithm was used to match patients. Categorical data are expressed as numbers and percentages, whereas continuous data are expressed as means and standard deviations. Paired t-test and generalized estimating equations were used to compare the prevalence of diseases and categorical variables. A P-value of $<0.05$ was considered statistically significant. All statistical analyses were performed using SAS statistical software package ver. 9.2 (SAS Institute Inc., Cary, NC, USA). 


\section{RESULTS}

\section{Patient's Baseline Characteristics and Laboratory Results}

A total of 1,514 Korean Americans visited the Gangnam Severance Hospital for health checkup from February 2010 to May 2015, and 1,514 native Koreans were selected as age-/sex-matched controls to overcome possible selection bias. Therefore, 3,028 participants were enrolled in this study. The mean age of Korean Americans and native Koreans were $53.6 \pm 8.4$ years and $53.7 \pm 8.3$ years, respectively. The ratio of female and male Korean Americans and native Koreans were 47.4:52.6 and 46.8:53.2, respectively. High blood pressure, high cholesterol, and high LDL were more frequent among Korean Americans

Table 1. Characteristics of native Koreans and Korean Americans

\begin{tabular}{lccc}
\hline \multicolumn{1}{c}{ Characteristic } & $\begin{array}{c}\text { Native Koreans } \\
(\mathrm{n}=1,514)\end{array}$ & $\begin{array}{c}\text { Korean Americans } \\
(\mathrm{n}=1,514)\end{array}$ & P-value \\
\hline Age $(\mathrm{y})$ & $53.62 \pm 8.43$ & $53.68 \pm 8.33$ & 0.1389 \\
Sex & & & 0.248 \\
$\quad$ Male & $709(46.83)$ & $717(47.36)$ & \\
$\quad$ Female & $805(53.17)$ & $797(52.64)$ & \\
Obesity & $514(34.11)$ & $480(31.87)$ & 0.1838 \\
High blood pressure & $303(20.12)$ & $356(23.62)$ & 0.0177 \\
High fasting glucose level & $134(8.89)$ & $103(6.83)$ & 0.0311 \\
High total cholesterol & $207(13.74)$ & $254(16.85)$ & 0.0179 \\
High low-density lipoprotein & $200(13.27)$ & $249(16.52)$ & 0.0122 \\
Low high-density lipoprotein & $296(19.64)$ & $241(15.99)$ & 0.0091 \\
High triglycerides & $238(15.79)$ & $181(12.01)$ & 0.0028 \\
\hline
\end{tabular}

Values are presented as mean \pm standard deviation or number (\%). Calculated by paired t-test and generalized estimating equations after matching for age and sex.

Table 2. Laboratory data of native Koreans and Korean Americans

\begin{tabular}{|c|c|c|c|}
\hline Laboratory data & $\begin{array}{l}\text { Native Koreans } \\
(n=1,514)\end{array}$ & $\begin{array}{l}\text { Korean Americans } \\
\quad(n=1,514)\end{array}$ & P-value \\
\hline Hemoglobin $(\mathrm{g} / \mathrm{dL})$ & $14.43 \pm 1.41$ & $14.36 \pm 1.45$ & 0.0763 \\
\hline White blood cell $(10 \wedge 3 / \mu \mathrm{L})$ & $5.99 \pm 1.58$ & $6.11 \pm 1.75$ & 0.039 \\
\hline $\begin{array}{l}\text { Aspartate aminotransferase } \\
\text { (IU/L) }\end{array}$ & $24.64 \pm 11.69$ & $25.23 \pm 24.82$ & 0.3976 \\
\hline $\begin{array}{l}\text { Alanine aminotransferase } \\
\text { (IU/L) }\end{array}$ & $24.33 \pm 16.49$ & $26.52 \pm 40.42$ & 0.0505 \\
\hline $\begin{array}{l}\text { Gamma } \\
\text { glutamyl transferase (IU/L) }\end{array}$ & $35.82 \pm 71.37$ & $31.23 \pm 35.17$ & 0.0241 \\
\hline Creatinine (mg/dL) & $0.77 \pm 0.19$ & $0.78 \pm 0.2$ & 0.0158 \\
\hline C-reactive protein (mg/L) & $1.36 \pm 3.03$ & $1.73 \pm 5.22$ & 0.0194 \\
\hline $\begin{array}{l}\text { Thyroid-stimulating } \\
\text { hormone (mclU/mL) }\end{array}$ & $2.46 \pm 3.69$ & $2.26 \pm 2.45$ & 0.0806 \\
\hline Free T4 (ng/dL) & $1.27 \pm 0.23$ & $1.31 \pm 0.2$ & $<0.0001$ \\
\hline$\alpha$-Fetoprotein (ng/mL) & $2.95 \pm 1.82$ & $3.05 \pm 2.09$ & 0.1466 \\
\hline $\begin{array}{l}\text { Carcinoembryonic antigen } \\
(\mathrm{ng} / \mathrm{mL})\end{array}$ & $1.89 \pm 2.94$ & $1.73 \pm 1.3$ & 0.0541 \\
\hline $\begin{array}{l}\text { Carbohydrate antigen 19-9 } \\
(\mathrm{U} / \mathrm{mL})\end{array}$ & $7.98 \pm 8.68$ & $9.13 \pm 26.87$ & 0.1023 \\
\hline Cancer antigen 125 (U/mL) & $13.23 \pm 13.97$ & $14.64 \pm 21.01$ & 0.1115 \\
\hline $\begin{array}{l}\text { Prostate-specific antigen } \\
(\mathrm{ng} / \mathrm{mL})\end{array}$ & $1.19 \pm 1.15$ & $1.22 \pm 1.31$ & 0.8056 \\
\hline
\end{tabular}

Values are presented as mean \pm standard deviation. Calculated by paired t-test and generalized estimating equations after matching for age and sex.
$(\mathrm{P}<0.05)$. By contrast, high fasting glucose level, low HDL, and high TG were more prevalent among native Koreans $(\mathrm{P}<0.05)$. Tumor markers were not significantly different between the two groups (Tables 1,2).

\section{Prevalence of Gastrointestinal Diseases}

Reflux esophagitis, colorectal polyp (only adenoma), and hemorrhoids were more prevalent among Korean Americans than among native Koreans (12.92\% versus $10.08 \%, 37.69 \%$ versus $28.68 \%, 32.23$ versus $29.96 \% ; \mathrm{P}<0.05)$. However, the prevalence of gastric ulcer was higher among native Koreans than among Korean Americans (5.53\% versus $3.01 \%, \mathrm{P}<0.05)$ (Table 3).

\section{Prevalence of Other Diseases}

No significant differences were observed in the prevalence of thyroid cancer, brain tumor, prostate cancer, lung cancer, chronic liver disease, hepatocellular carcinoma, renal cell carcinoma, pancreatic mass, adrenal mass, and CAD between Korean Americans and native Koreans (Table 4). However, the prevalence of prostate benign prostatic hyperplasia (BPH) was higher among Korean Americans than among native Koreans $(30.21 \%$ versus $14.29 \%, \mathrm{P}<0.0005)$. In addition, although not

Table 3. Prevalence of gastrointestinal disease in native Koreans and Korean Americans

\begin{tabular}{lccc}
\hline \multicolumn{1}{c}{ Variable } & Native Koreans & Korean Americans & P-value \\
\hline Reflux esophagitis & $144 / 1,428(10.08)$ & $193 / 1,494(12.92)$ & 0.0140 \\
Gastric ulcer & $79 / 1,428(5.53)$ & $45 / 1,494(3.01)$ & 0.0007 \\
Duodenal ulcer & $59 / 1,428(4.13)$ & $61 / 1,494(4.08)$ & 0.9474 \\
Gastric cancer & $3 / 1,428(0.21)$ & $1 / 1,494(0.07)$ & 0.3010 \\
Colorectal polyps & $117 / 408(28.68)$ & $421 / 1,117(37.69)$ & 0.0471 \\
$\quad$ & & & \\
$\quad$ (adenoma in pathologic & & & \\
Colorectings) & $1 / 408(0.25)$ & $1 / 1,117(0.09)$ & 0.5505 \\
Hemorrhoids & $110 / 408(29.96)$ & $360 / 1,117(32.23)$ & 0.0422 \\
\hline
\end{tabular}

Values are presented as number (\%). Calculated by generalized estimating equations after matching for age and sex.

Table 4. Prevalence of other diseases in native Koreans and Korean Americans

\begin{tabular}{lccc}
\hline \multicolumn{1}{c}{ Variable } & Native Koreans & Korean Americans & P-value \\
\hline Thyroid cancer & $0 / 79(0)$ & $3 / 1,064(0.28)$ & 0.0828 \\
Brain tumor & $0 / 11(0)$ & $1 / 385(0.26)$ & 0.0729 \\
Prostate cancer & $0 / 77(0)$ & $3 / 513(0.58)$ & 0.0824 \\
$\begin{array}{l}\text { Benign prostatic } \\
\quad \text { hyperplasia }\end{array}$ & $11 / 77(14.29)$ & $155 / 513(30.21)$ & 0.0004 \\
Lung cancer & $0 / 44(0)$ & $1 / 982(0.10)$ & 0.3171 \\
$\quad \begin{array}{l}\text { Chronic liver disease } \\
\text { Hepatocellular }\end{array}$ & $0 / 37(0)$ & $0 / 671(0)$ & 0.3169 \\
$\quad$ carcinoma & $0 / 37(0)$ & $1 / 671(0.15)$ & 0.3996 \\
Renal cell cancer & $1 / 37(2.70)$ & $3 / 671(0.45)$ & 0.3996 \\
$\begin{array}{l}\text { Pancreatic mass } \\
\text { (only cyst) }\end{array}$ & $0 / 37(0)$ & $2 / 671(0.30)$ & 0.1567 \\
Adrenal mass & & & \\
$\quad$ (only adenoma) & $0 / 37(0)$ & $3 / 671(0.45)$ & 0.0826 \\
Coronary artery disease & $3 / 12(25.00)$ & $103 / 376(27.39)$ & 0.8021 \\
\hline
\end{tabular}

Values are presented as number (\%). Calculated by generalized estimating equations after matching for age and sex. 
Table 5. Dietary pattern questionnaire of native Koreans and Korean Americans

\begin{tabular}{|c|c|c|c|}
\hline Questionnaire & $\begin{array}{l}\text { Native Koreans } \\
(\mathrm{n}=272)\end{array}$ & $\begin{array}{l}\text { Korean Americans } \\
\quad(n=173)\end{array}$ & P-value \\
\hline 1. Three meals a day & & & 0.4894 \\
\hline Yes & $68(60.71)$ & $59(52.68)$ & \\
\hline Sometimes & $23(20.54)$ & $27(24.11)$ & \\
\hline No & $21(18.75)$ & $26(23.21)$ & \\
\hline 2. Meals at the appointed time & & & 0.2846 \\
\hline Yes & $63(56.76)$ & $60(54.05)$ & \\
\hline Sometimes & $28(25.23)$ & $38(34.23)$ & \\
\hline No & $20(18.02)$ & $13(11.71)$ & \\
\hline 3. Time for one meal & & & 0.0122 \\
\hline Less than $15 \mathrm{~min}$ & $54(48.65)$ & $37(33.33)$ & \\
\hline 15 to $30 \mathrm{~min}$ & $56(50.45)$ & $66(59.46)$ & \\
\hline More than 30 min & $1(0.90)$ & $8(7.21)$ & \\
\hline 4. Overeating & & & 0.7746 \\
\hline Yes & $15(13.51)$ & $18(16.22)$ & \\
\hline Sometimes & $67(60.36)$ & $62(55.86)$ & \\
\hline No & $29(26.13)$ & $31(27.93)$ & \\
\hline 5. Eating out & & & 0.3417 \\
\hline Yes & $34(31.48)$ & $44(40.74)$ & \\
\hline Sometimes & $64(59.26)$ & $57(52.78)$ & \\
\hline No & $10(9.26)$ & $7(6.48)$ & \\
\hline 6. Water drinking (6 to 8 cups/d) & & & 0.4343 \\
\hline Yes & $39(35.14)$ & $43(38.74)$ & \\
\hline Sometimes & $52(46.85)$ & $43(38.74)$ & \\
\hline No & $20(18.02)$ & $25(22.52)$ & \\
\hline 7. Interest in nutrition & & & 0.5491 \\
\hline Much & $32(29.36)$ & $39(35.78)$ & \\
\hline Middle & $61(55.96)$ & $54(49.54)$ & \\
\hline Less & $16(14.68)$ & $16(14.68)$ & \\
\hline 8. Grain & & & 0.7827 \\
\hline $1-2$ times/d & $75(68.18)$ & 78 (70.91) & \\
\hline 3 times/d & $33(30.00)$ & $29(26.36)$ & \\
\hline 4 times/d & $2(1.82)$ & $3(2.73)$ & \\
\hline 9. Protein & & & 0.6294 \\
\hline $1-2$ times/d & $90(82.57)$ & $95(87.16)$ & \\
\hline 3 times/d & $17(15.60)$ & $12(11.01)$ & \\
\hline 4 times/d & $2(1.83)$ & $2(1.83)$ & \\
\hline 10. Vegetables & & & 0.1429 \\
\hline Less than 1 time/d & $52(47.71)$ & $61(55.96)$ & \\
\hline 2 times/d & $43(39.45)$ & $42(38.53)$ & \\
\hline 3 times/d & $14(12.84)$ & $6(5.50)$ & \\
\hline 11. Vegetable oil & & & 0.43 \\
\hline 0 to 2 times/wk & $63(58.88)$ & $59(55.14)$ & \\
\hline 3 to 5 times/wk & $39(36.45)$ & $38(35.51)$ & \\
\hline 6 to 7 times/wk & $5(4.67)$ & $10(9.35)$ & \\
\hline 12. Fruits & & & 0.4268 \\
\hline 0 to 2 times/wk & $42(38.18)$ & $34(30.91)$ & \\
\hline 3 to 5 times/wk & $49(44.55)$ & $51(46.36)$ & \\
\hline 6 to 7 times/wk & $19(17.27)$ & $25(22.73)$ & \\
\hline 13. Milk and dairy products & & & 0.9616 \\
\hline 0 to 2 times/wk & $71(63.96)$ & $69(62.16)$ & \\
\hline 3 to 5 times/wk & $29(26.13)$ & $30(27.03)$ & \\
\hline 6 to 7 times/wk & $11(9.91)$ & $12(10.81)$ & \\
\hline 14. Sugary food & & & 0.2219 \\
\hline 0 to 2 times/wk & $50(45.05)$ & $53(47.75)$ & \\
\hline 3 to 5 times/wk & $42(37.84)$ & 48 (43.24) & \\
\hline 6 to 7 times/wk & $19(17.12)$ & $10(9.01)$ & \\
\hline
\end{tabular}

Table 5. Continued

\begin{tabular}{lccc}
\hline Questionnaire & $\begin{array}{c}\text { Native Koreans } \\
(\mathrm{n}=272)\end{array}$ & $\begin{array}{c}\text { Korean Americans } \\
(\mathrm{n}=173)\end{array}$ & P-value \\
\hline 15. Salty food & & & 0.2219 \\
0 to 2 times/wk & $50(45.05)$ & $53(47.75)$ & \\
3 to 5 times/wk & $42(37.84)$ & $48(43.24)$ & \\
6 to 7 times/wk & $19(17.12)$ & $10(9.01)$ & \\
16. Greasy food & & & 0.0695 \\
0 to 2 times/wk & $94(85.45)$ & $82(74.55)$ & \\
3 to 5 times/wk & $15(13.64)$ & $28(25.45)$ & \\
6 to 7 times/wk & $1(0.91)$ & $0(0)$ & \\
17. Egg yolk & & & \\
0 to 2 times/wk & $88(80.00)$ & $77(70.00)$ & \\
3 to 5 times/wk & $21(19.09)$ & $30(27.27)$ & \\
6 to 7 times/wk & $1(0.91)$ & $3(2.73)$ & \\
18. Coffee and infusions & & & 0.0567 \\
0 to 2 times/wk & $37(34.26)$ & $52(48.15)$ & \\
3 to 5 times/wk & $40(37.04)$ & $24(22.22)$ & \\
6 to 7 times/wk & $31(28.70)$ & $32(29.63)$ & \\
19. Hot and spicy seasoning & & & 0.3154 \\
0 to 2 times/wk & $70(66.04)$ & $80(75.47)$ & \\
3 to 5 times/wk & $33(31.13)$ & $23(21.70)$ & \\
6 to 7 times/wk & $3(2.83)$ & $3(2.83)$ & \\
20. Drinking & & & 0.9048 \\
0 to 2 times/wk & $76(85.39)$ & $78(87.64)$ & \\
3 to 5 times/wk & $12(13.48)$ & $10(11.24)$ & \\
6 to 7 times/wk & $1(1.12)$ & $1(1.12)$ & \\
\hline
\end{tabular}

Values are presented number (\%). Calculated by paired t-test and generalized estimating equations after matching for age and sex.

statistically significant, $>20 \%$ of participants in both groups had high $\mathrm{CAD}$ prevalence rate.

\section{Dietary Pattern Questionnaire}

Table 5 shows a comparison of dietary pattern questionnaires used among Korean Americans and native Koreans. Among these, only "time for one meal" showed significance $(\mathrm{P}<0.05)$. Native Koreans had a very short meal time of 15 minutes ( $48.7 \%$ versus $33.3 \%$ ), whereas Korean Americans ate more slowly for $15-30$ minutes (59.5\% versus $50.5 \%$ ) or $>30$ minutes $(7.2 \%$ versus $0.9 \%$ ).

\section{DISCUSSION}

In this study, reflux esophagitis, colorectal polyp, hemorrhoids, and BPH were more prevalent among Korean Americans, whereas only gastric ulcer was more prevalent among native Koreans. However, both groups had high prevalence of $\mathrm{CAD}$, although not statistically significant. Dietary patterns were not significant between the two groups. This is the first study to compare between the disease and dietary patterns among Korean Americans and native Koreans.

$\mathrm{CAD}$ is the leading cause of death worldwide ${ }^{6)} \mathrm{CAD}$ rapidly develops in individuals living in developing countries or in those at the threshold of entry into developed countries owing to the rapid lifestyle changes such as Westernized eating habits because of industrialization and urbanization and reduced physical activity. ${ }^{6)}$ In Korea, the in- 
cidence of arteriosclerosis has been increasing; the mortality rate due to ischemic heart disease per 100,000 populations has nearly doubled, ranging from 13.3 in 1993 to 24.6 in $2003 .{ }^{7)}$ In this study, approximately 27.39\% of Korean Americans and 25\% of native Koreans had CAD. However, existing risk factors and exercise stress test do not find the majority of patients at risk for $\mathrm{CAD}$. CAD remains asymptomatic until symptom occurrence or stress tests are positive. Some patients diagnosed with $\mathrm{CAD}$ frequently showed negative results during exercise stress tests or other tests. Therefore, the detection and prediction of $\mathrm{CAD}$ without symptoms is very important. With coronary CT angiography, quantification of coronary artery calcium has been shown to be reliable, reproducible, and predictive of cardiovascular risk. ${ }^{8)}$

The prevalence of colorectal polyp is generally higher in the Western population than in the Asian population. The prevalence of colonic polyp in Western countries ranged from $29.4 \%$ to $58 \%$, whereas that in Asian countries ranged from $16.3 \%$ to $18.5 \% .^{9)}$ In contrast, Lam et al., ${ }^{10)}$ one of the first large studies to examine the use of colonoscopy in an Asian American population, suggested that the prevalence of advanced colorectal neoplasia among Asian Americans was similar to that among non-Asians. Approximately 37.69\% of Korean Americans and $28.68 \%$ of native Koreans had colorectal polyps. This result is similar to that of a previous study, which reported that $34 \%$ of asymptomatic Asian American men and $21 \%$ of women had colorectal neoplasm. ${ }^{10)}$ The following factors possibly contributed to the increased prevalence of colorectal polyps among Asian Americans. First, increased exposure to high-fat diet in Asian Americans may contribute to high prevalence of adenoma along with CRC risk. ${ }^{10)}$ Second, Asian Americans have many critical barriers to receiving preventive health services in the United States. Previous studies found that Asian Americans have lower CRC screening rates than non-Hispanic white Americans. ${ }^{11)}$ Moreover, Korean Americans have lower rates of CRC screening awareness and uptake. ${ }^{4)}$ However, the low prevalence of colon polyps among native Koreans may partially account for periodic diagnostic colonoscopy or the removal of small polyps during screening. According to the recently published Korean guidelines for CRC screening and polyp detection, asymptomatic adults aged 45-80 years are recommended to undergo annual or biennial fecal immunochemical test. Selective colonoscopy is also recommended considering individual preference and CRC risk. ${ }^{12)}$ Thus, Korean Americans should also follow these Korean guidelines. In our study, the incidence of gastric ulcer was significantly higher among native Koreans than among Korean Americans. A study by Kim et al. ${ }^{9)}$ reported similar results, indicating that $3.4 \%$ of native Koreans and $2.8 \%$ of Korean Americans developed gastric ulcer. Further studies are needed to analyze risk factors between the two groups.

The prevalence of reflux esophagitis was lower in the Asian population than in the Western population; however, Korean studies have reported that the prevalence of reflux esophagitis ranged from $8 \%$ to $11.8 \%{ }^{13,14)}$ Approximately $12.92 \%$ of Korean Americans and $10.08 \%$ of native Koreans had reflux esophagitis. Several risk factors of reflux esophagitis, such as hiatal hernia, male sex, obesity, and alcohol con- sumption, have been reported. ${ }^{14,15)}$ However, none of the items examined were considered as risk factors of reflux esophagitis. Hence, further studies are needed to evaluate risk factors of reflux esophagitis among Korean Americans.

Hemorrhoid is the most common anal disease in the Korean adult population. ${ }^{16)}$ A Korean study reported that the prevalence of hemorrhoids diagnosed by physicians was $7.2 \% .{ }^{16)}$ Another study reported that the prevalence of hemorrhoids ranged from $4.4 \%$ to $86 \%{ }^{17,18)}$ In this study, the prevalence of hemorrhoids was higher among Korean Americans than among native Koreans. Several factors have been suggested to contribute to the occurrence of hemorrhoids in Koreans, such as obesity, abdominal obesity, depression, and past pregnancy. ${ }^{16)}$ In women, self-reported hemorrhoids were more prevalent in those with less fiber intake. ${ }^{16)}$ In this study, the proportion of people eating vegetables less than once a day was higher among Korean Americans than among native Koreans, and the rate of eating more than three times a day was higher among native Koreans than among Korean Americans. This can be due to the higher prevalence of hemorrhoids among Korean Americans than among native Koreans. Hence, preventive education should be implemented to Korean Americans, noting that vegetable intake is an important factor associated with hemorrhoids.

$\mathrm{BPH}$ is one of the most common conditions in aging men and often presents as lower urinary tract symptoms related to voiding problems and bladder irritability. ${ }^{19)}$ Although no accurate Korean statistics exist on the prevalence of $\mathrm{BPH}$, the prevalence of prostate hyperplasia in men aged over 40 years who underwent general health checkups was $25.9 \%{ }^{20)}$ In addition, the prevalence of prostate hypertrophy markedly increases with age. Moreover, the prevalence of BPH was higher among Korean Americans than among native Koreans (30.21\% versus $14.29 \%$ ). Metabolic syndrome, such as obesity and diabetes, is a wellknown causative agent of BPH. ${ }^{21,22)}$ In contrast, increased physical activity and exercise have been associated with decreased risks of $\mathrm{BPH} .{ }^{23)}$ With regard to nutrition, excessive intake of total energy, total protein, red meat, fat, milk and dairy products, cereals, bread, poultry, and starch potentially increases the risk of BPH, whereas intake of vegetables, fruits, polyunsaturated fatty acids, linoleic acid and vitamin D, vitamin E, lycopene, selenium, and carotene potentially decreases risk of $\mathrm{BPH} .{ }^{24)}$ However, in our study, although the prevalence of $\mathrm{BPH}$ among Korean Americans was extremely higher than that among native Koreans, none of these risk factors were present.

Diet is one of several changes occurring as a result of immigration and can have a great impact on disease prevalence. Dietary changes, including increased intakes of total energy and fat, that are observed in Asian Americans have been hypothesized as risk factors for various chronic diseases. ${ }^{25)}$ Therefore, the study on the relationship between dietary patterns and disease prevalence of native Koreans and Korean Americans may provide important information to prevent disease. One study reported that compared with native Korean women, USborn Korean American women were more likely to be overweight or obese and had higher intake of energy from fat and lower intake of 
fruits and vegetables. ${ }^{26)}$ Moreover, US-born women consumed less sodium than did Korea-born women. ${ }^{26)}$ In another study, calcium intake of Korean Americans was low, particularly for elderly people. ${ }^{27)}$ However, no significant differences were observed among the 20-item dietary pattern questionnaire in this study.

We do acknowledge that this study has limitations. First, the sample of both groups is not representative of all native Koreans and Korean Americans because this is a cross-sectional study conducted in a single health promotion center and is not a random sample in Korean Americans. This may have been a source of selection bias. To make up for this selection bias, age- and sex-matched native Koreans and Korean Americans were selected. However, Korean Americans who came to Korea from the United States and underwent a health checkup were more aware of health-related symptoms than native Koreans. Hence, this selection bias will not be resolved through age-sex matching. In addition, regarding the rare and common diseases, measuring the prevalence rate to approximately 1,000 could lead to serious bias. Second, patients' length of residency in the United States was not obtained, and immigrants were not distinguished by generation. Park et al. ${ }^{26)}$ reported that health-related behaviors and intakes of nutrients and foods in Korean Americans were affected by their place of birth, but not by their parents' place of birth. Compared to Korea-born women, US-born women were more likely to use preventive medical services and showed more Westernized dietary characteristics. ${ }^{26)}$ Third, as items in the dietary questionnaire are labeled as ingredients instead of food, people may have difficulty in understanding. However, differences between commercial foods in the United States and in Korea may be large. Additionally, the lack of subdivision of the items can also be considered as a limitation. The greatest limitation is the small number of samples selected to answer the dietary questionnaire.

In conclusion, this study showed that the prevalence of several diseases among Korean Americans differed from that among native Koreans. This result can predict the future burden of disease among Korean Americans. Further studies that overcome the limitations in this study are needed and may play a major role in recommending a screening and surveillance strategy for Korean Americans in the future.

\section{CONFLICT OF INTEREST}

No potential conflict of interest relevant to this article was reported.

\section{ORCID}

So Young Jo: https://orcid.org/0000-0002-4995-6842

Hyojin Park: https://orcid.org/0000-0003-4814-8330

Byoung Kwon Lee: https://orcid.org/0000-0001-9259-2776

Su Jung Baik: https://orcid.org/0000-0002-3790-7701

Hyun Ju Lee: https://orcid.org/0000-0003-0183-9935

Yoo Mi Park: https://orcid.org/0000-0002-3642-7300

\section{REFERENCES}

1. Ministry of Health and Welfare. Cancer control 2015: 2nd period of 10year plan for national cancer control. Sejong: Ministry of Health and Welfare; 2006.

2. Kim Y, Jun JK, Choi KS, Lee HY, Park EC. Overview of the national cancer screening programme and the cancer screening status in Korea. Asian Pac J Cancer Prev 2011;12:725-30.

3. Kagawa-Singer M, Pourat N, Breen N, Coughlin S, Abend McLean T, et al. Breast and cervical cancer screening rates of subgroups of Asian American women in California. Med Care Res Rev 2007;64:706-30.

4. Oh KM, Jacobsen KH. Colorectal cancer screening among Korean Americans: a systematic review. J Community Health 2014;39:193200.

5. Oh KM, Kreps GL, Jun J, Ramsey L. Cancer information seeking and awareness of cancer information sources among Korean Americans. J Cancer Educ 2011;26:355-64.

6. Reddy KS, Yusuf S. Emerging epidemic of cardiovascular disease in developing countries. Circulation 1998;97:596-601.

7. Korea National Statistical Office. Annual report on the cause of death statistics. Daejeon: Statistics Korea; 2004.

8. Budoff MJ, Georgiou D, Brody A, Agatston AS, Kennedy J, Wolfkiel C, et al. Ultrafast computed tomography as a diagnostic modality in the detection of coronary artery disease: a multicenter study. Circulation 1996;93:898-904.

9. Kim HS, Baik SJ, Kim KH, Oh CR, Lee JH, Jo WJ, et al. Prevalence of and risk factors for gastrointestinal diseases in Korean Americans and native Koreans undergoing screening endoscopy. Gut Liver 2013;7:53945.

10. Lam KD, Garcia RT, Nguyen LH, Trinh H, Triadafilopoulos G, Phan JT, et al. Prevalence of colorectal neoplasms in Asian Americans. Dig Dis Sci 2009;54:160-7.

11. Homayoon B, Shahidi NC, Cheung WY. Impact of Asian ethnicity on colorectal cancer screening: a population-based analysis. Am J Clin Oncol 2013;36:167-73.

12. Sohn DK, Kim MJ, Park Y, Suh M, Shin A, Lee HY, et al. The Korean guideline for colorectal cancer screening. J Korean Med Assoc 2015;58: 420-32.

13. Kim N, Lee SW, Cho SI, Park CG, Yang CH, Kim HS, et al. The prevalence of and risk factors for erosive oesophagitis and non-erosive reflux disease: a nationwide multicentre prospective study in Korea. Aliment Pharmacol Ther 2008;27:173-85.

14. Hwang JK, Kim J, Hong SG, Jung SJ, Joo MK, Lee BJ, et al. A prospective multicenter study on the prevalence and symptoms of erosive reflux esophagitis in secondary and tertiary hospitals in Korea. Korean J Gastroenterol 2009;53:283-91.

15. Gunji T, Sato H, Iijima K, Fujibayashi K, Okumura M, Sasabe N, et al. Risk factors for erosive esophagitis: a cross-sectional study of a large number of Japanese males. J Gastroenterol 2011;46:448-55.

16. Lee JH, Kim HE, Kang JH, Shin JY, Song YM. Factors associated with hemorrhoids in Korean adults: Korean national health and nutrition examination survey. Korean J Fam Med 2014;35:227-36.

17. Haas PA, Haas GP, Schmaltz S, Fox TA Jr. The prevalence of hemorrhoids. Dis Colon Rectum 1983;26:435-9. 
18. Johanson JF, Sonnenberg A. The prevalence of hemorrhoids and chronic constipation: an epidemiologic study. Gastroenterology 1990; 98:380-6.

19. Berry SJ, Coffey DS, Walsh PC, Ewing LL. The development of human benign prostatic hyperplasia with age. J Urol 1984;132:474-9.

20. Kwon NS, Jo MK, Park K. The relationship between the metabolic syndrome and the risk of benign prostatic hyperplasia: a hospital-based study from a health screening population. Korean J Urol 2007;48:101621.

21. Parsons JK, Messer K, White M, Barrett-Connor E, Bauer DC, Marshall LM, et al. Obesity increases and physical activity decreases lower urinary tract symptom risk in older men: the Osteoporotic Fractures in Men Study. Eur Urol 2011;60:1173-80.

22. Sarma AV, Parsons JK, McVary K, Wei JT. Diabetes and benign prostatic hyperplasia/lower urinary tract symptoms: what do we know? J Urol 2009;182(6 Suppl):S32-7.
23. Fowke JH, Phillips S, Koyama T, Byerly S, Concepcion R, Motley SS, et al. Association between physical activity, lower urinary tract symptoms (LUTS) and prostate volume. BJU Int 2013;111:122-8.

24. Kristal AR, Arnold KB, Schenk JM, Neuhouser ML, Goodman P, Penson DF, et al. Dietary patterns, supplement use, and the risk of symptomatic benign prostatic hyperplasia: results from the prostate cancer prevention trial. Am J Epidemiol 2008;167:925-34.

25. Davis J, Busch J, Hammatt Z, Novotny R, Harrigan R, Grandinetti A, et al. The relationship between ethnicity and obesity in Asian and Pacific Islander populations: a literature review. Ethn Dis 2004;14:111-8.

26. Park SY, Murphy SP, Sharma S, Kolonel LN. Dietary intakes and healthrelated behaviours of Korean American women born in the USA and Korea: the Multiethnic Cohort Study. Public Health Nutr 2005;8:90411.

27. Kim KK, Kohrs MB, Twork R, Grier MR. Dietary calcium intakes of elderly Korean Americans. J Am Diet Assoc 1984;84:164-9. 